\title{
Soil Microbial Biomass as an Edge Effect Indicator in Semi-Deciduous Seasonal Forest Fragments
}

\section{Mayana Oliveira Duarte Santos ${ }^{1}$ (D), Patrícia Anjos Bittencourt Barreto-Garcia ${ }^{1}$ (i), Emanuela Forestieri Gama-Rodrigues ${ }^{2}$ (i)}

\author{
${ }^{1}$ Universidade Estadual do Sudoeste da Bahia (UESB), Vitória da Conquista, BA, Brasil \\ ${ }^{2}$ Universidade Estadual do Norte Fluminense (UENF), Campos dos Goytacazes, RJ, Brasil
}

\begin{abstract}
This work had the objective to evaluate the activity and microbial biomass of the soil as an indicator of edge effect in Semi-Deciduous Seasonal Forest fragments. Three fragments of different sizes (small, medium and large) located in the Southwest region of Bahia state were evaluated, in which three sampling ranges were defined in each, and soil samples were collected. The carbon and nitrogen contents of the microbial biomass were determined by the fumigation-extraction method and soil respiration. The microbial biomass carbon (MBC), metabolic carbon quotient $\left(q \mathrm{CO}_{2}\right)$ and the microbial C:N and MBC:C ratios were discriminating indicators of the edge effect on the soil quality of the studied forest fragments. The integrated analysis of soil microbiological attributes is adequate to evaluate the edge effect in forest fragments. The size of the fragments and their isolation influence the $\mathrm{MBC}$ contents, showing greater vulnerability of the smaller fragments in relation to the actions of the external environment.
\end{abstract}

Keywords: fragmentation, microbial activity, forest soils. 


\section{INTRODUCTION AND OBJECTIVES}

Humankind has used forest resources for their development since the earliest times, which over the years has caused the original forest cover to change. As a consequence of this process, there is a reduction in native vegetation areas and the formation of forest fragments. In Brazil, the Atlantic Forest is the biome most affected by fragmentation. Its remnants have been reduced to about $13 \%$ of its original area and are mostly divided into fragments with an area of less than 100 hectares (Silva et al., 2016).

Within the Atlantic Forest biome, one of the phytophysiognomies most affected by the fragmentation process is the Semi-deciduous Seasonal Forest, which occurs in the transition zone with the Caatinga biome (Bahia state and Northeast of Minas Gerais) and in the South of the country (Iesb, 2007). However, even though its territory has been reduced, this formation is still little studied.

Forest fragmentation causes the division of a population into two or more non-interconnected subpopulations (Laurance et al., 2003). This results in an increase in the amount of edges and abrupt edges which are subject to higher temperature, luminosity, wind speed and low relative humidity due to higher exposure (Holanda et al., 2010). As a result of this influence, several ecosystem functions, including biological and hydrological cycles, are also altered.

In this way, the edge effect in the forest ecosystem can be reproduced in different ways, such as changes in biodiversity and species interactions (Laurance et al., 2011), plant composition and richness (Riguete et al., 2013), litter production and accumulation (Vidal et al., 2007), and soil attributes (Freitas et al., 2008; Santos et al., 2011). Such changes can be used to define edge effect indicators capable of reflecting the conservation status of forest fragments.

Any transformation in the ecosystem can directly alter soil characteristics such as density and porosity (Martinkoski et al., 2017), organic matter content, biological activity (Freitas et al., 2008), and, consequently, fertility. Thus, soil quality assessment may aid in interpreting the magnitude of the effects of natural or anthropogenic interferences on the ecosystem.

Soil quality is usually measured through its chemical, physical and biological attributes, which reflect soil condition and ecosystem sustainability (Araújo \& Monteiro, 2007). The biological attributes of the soil are considered sensitive indicators to the anthropic disturbances and modifications in the soil, allowing their use in studies related to the quality and maintenance of ecosystems (Pôrto et al., 2009).

Among soil biological attributes, microbial biomass (MB) represents the labile fraction of soil organic matter $(\mathrm{OM})$ and has a dynamic nature, being easily affected by biotic and abiotic factors (Gama-Rodrigues \& Gama-Rodrigues, 2008). For this reason, although it represents a small proportion of the organic carbon in the soil, $\mathrm{MB}$ is usually more responsive to initial changes in OM levels than the soil organic $\mathrm{C}$ content (Anderson \& Domsch, 1993; Gama-Rodrigues \& Gama-Rodrigues, 2008). Thus, evaluating microbial biomass can help to understand the behavior of soil microorganisms, for example indicating the decomposition rate of organic matter and the release of carbon and nutrients into the soil (Padilha et al., 2014).

There are still few studies in Brazil related to the evaluation of the edge effect on soil quality in general, and in particular on the microbiological attributes of the soil. In this context, studies related to this theme may significantly contribute to understand the real consequences of fragmentation on the soil dynamics, in addition to providing subsidies for elaboration of more efficient conservation techniques.

This work had the objective to evaluate the activity and microbial biomass of the soil as an indicator of edge effect in Semi-deciduous Seasonal Forest fragments.

\section{MATERIALS AND METHODS}

\subsection{Characterization of the study area}

The study area is located in the city of Vitória da Conquista (BA), in the Planalto da Conquista, at altitudes varying from 857 to $1,000 \mathrm{~m}$. The municipality is inserted in a transitional stretch between the Caatinga and Atlantic Forest biomes and its predominant vegetation is Montana Semi-deciduous Seasonal Forest, regionally known as cipó forest. The climate of the region is tropical altitude (Cwb, according to the Köppen classification), with an average temperature of $25^{\circ} \mathrm{C}$ and annual precipitation of $850 \mathrm{~mm}$. 
The Conquista Plateau Forest is a relatively low forest, with trees that have an average height between 10 and 15 meters, about 50\% deciduous and with a species predominance of the Parapiptadenia and Anadenanthera genera, normally associated to the Cavanillesia, Tabebuia and Cedrela genera (IBGE, 2012).

\subsection{Forest fragment selection}

Three fragments of semi-deciduous seasonal forest were selected, a small one ( $7.3 \mathrm{ha})$, one of medium size (45 ha) and one of large size (142 ha), all with visually similar forest structure (given the stratification, tree sizes, and life forms present) and with similar successional and historical stages of disturbance. The selected fragments also had the same environmental situation, which was predominantly agricultural, and soils with clayey texture, classified as Dystrophic Red-Yellow Latosol. In addition, the fragments presented different characteristics in relation to the landscape: the small fragment (fragment 1) and the middle fragment (fragment 2) were totally isolated from other forest patches by agricultural areas, while the large fragment (fragment 3 ) was connected through a forest corridor to two smaller fragments, which were not evaluated in this study.

Fragment 1 is located in the vicinity of the BR-116 highway ( $14^{\circ} 56^{\prime} 40^{\prime \prime} \mathrm{S}$ and $\left.40^{\circ} 53^{\prime} 50^{\prime \prime} \mathrm{W}\right)$. Fragment 2 is located in the Agricultural Field of the State University of Southwest Bahia (Uesb), Campus of Vitória da Conquista (14'52' 46” S and 40 47' 34” W). Fragment 3 is located near the BA-263 highway, between the municipalities of Vitória da Conquista and Barra do Choça (14 52' 53" S and 40 41'33” W).

The Trakemaker Pro software was used in order to characterize the condition of the fragments in the landscape (Table 1), incorporating images from Google Earth from the last quarter of 2014, from which the total area of each fragment (ha) was obtained; nuclear area (ha) - fragment area excluding edges of $50 \mathrm{~m}$ (Murcia, 1995); distance from each fragment to other forest fragments greater than 50 ha (ISO) and proximity to forest fragments (PROX) - obtained by the formula $\mathrm{PROX}=\mathrm{S}\left(\mathrm{A} / \mathrm{D}^{2}\right)$, where $\mathrm{A}$ corresponds to the area of the neighboring fragment $\left(\mathrm{m}^{2}\right)$ and $\mathrm{D}$ the distance edge to edge between the main fragment and the neighboring fragment, considering a maximum radius of $800 \mathrm{~m}$ from the edge, as adopted by Vidal et al. (2007).

\subsection{Delimitation of sampling ranges}

Three sampling ranges were defined in each of the forest fragments: (1) edge - positioned at the edge of the forest, $0-10 \mathrm{~m}$ from the edge; (2) transition intermediate range, located 40-50 $\mathrm{m}$ from the edge, representing a transition zone within the forest; (3) interior - corresponding to the fragment matrix, located in the half of the total distance between the ends of each fragment, in the sense of traversing the demarcation of the strips $(180,400$, and $500 \mathrm{~m}$, respectively, for fragments 1, 2 and 3).

\subsection{Soil collection}

Soil samples were taken in September 2015. Three plots of $10 \times 30 \mathrm{~m}\left(300 \mathrm{~m}^{2}\right)$ were installed at random in each of the strips. In each plot, 10 simple soil samples were collected to form a composite of the $0-10 \mathrm{~cm}$ layer.

\subsection{Soil chemical analysis}

The soil samples were analyzed for $\mathrm{P}$ and $\mathrm{K}$ (extractable by $\mathrm{Mehlich}^{-1}$ ), $\mathrm{Ca}, \mathrm{Mg}, \mathrm{Al}$ (exchangeable for $\mathrm{KCl} 1 \mathrm{~mol} \mathrm{~L}^{-1}$ ), organic $\mathrm{C}$ by oxidation with $\mathrm{K}_{2} \mathrm{Cr}_{2} \mathrm{O}_{7}$ $1.25 \mathrm{~mol} \mathrm{~L}^{-1}$ in acid medium, total $\mathrm{N}$ by the Kjeldahl method, $\mathrm{pH}$ (in water) and granulometry, as described

Table 1. Indices referring to the spatial configuration of the studied fragments (Vitória da Conquista-BA).

\begin{tabular}{|c|c|c|c|c|c|}
\hline \multirow{2}{*}{ Fragment } & \multicolumn{2}{|c|}{ Area (ha) } & \multirow{2}{*}{ Elevation (m) } & \multirow{2}{*}{ ISO (m) } & \multirow{2}{*}{$\operatorname{PROX}^{(1)}(\mathrm{m})$} \\
\hline & Total & Nuclear & & & \\
\hline 1 & 7.3 & 2.5 & 890 & 683.0 & 0.16 \\
\hline 2 & 45.0 & 32.0 & 915 & 661.5 & 2.87 \\
\hline 3 & 142.0 & 113 & 930 & 342.5 & 29.48 \\
\hline
\end{tabular}

In which: 1: small-sized fragment (7.3 ha); 2: medium-sized fragment (45 ha); 3: large fragment (142 ha); ISO: isolation index and PROX: proximity index. 
by Embrapa (1997). Table 2 summarizes the obtained results, presenting the chemical and granulometric characterization of the soil (layer $0-10 \mathrm{~cm}$ ) in the different strips of the three studied forest fragments.

\subsection{Analysis of soil microbial biomass}

For the microbial biomass evaluations, the soil samples were homogenized and sieved with $2 \mathrm{~mm}$ mesh, incubated for seven days in a flask containing one vial of water and another with $1 \mathrm{~mol} \mathrm{~L}^{-1} \mathrm{NaOH}$ to absorb $\mathrm{CO}_{2}$ from the soil and to eliminate the effect of sieving, since this fragments the soil organic matter, making it more available to microbial attack. After this procedure, the moisture content of the soil samples was adjusted to $40 \%$ saturation capacity.

The microbial biomass of the soil was determined by the fumigation-extraction method, adopting the approach proposed by Tate et al. (1988) for C, and the method by Joergensen \& Brookes (1990) for N. Microbial activity was measured in terms of soil respiration $\left(\mathrm{CO}_{2}\right.$ released). The amount of $\mathrm{CO}_{2}$ released was estimated over a seven-day incubation period, using jars containing two glass flasks, one with soil $(50 \mathrm{~g})$ and another with $10 \mathrm{ml}$ of $1 \mathrm{~mol} \mathrm{~L}^{-1}$ $\mathrm{NaOH}$. The jars were hermetically sealed and the $\mathrm{NaOH}$ solution was titrated with $0.5 \mathrm{~mol} \mathrm{~L}^{-1} \mathrm{HCl}$ after the incubation period, using 2 drops of the phenolphthalein indicator.

Next, microbiological indexes were determined based on the obtained data: $\mathrm{C}$ ratio of microbial biomass/organic $\mathrm{C}$ (MBC:C), $\mathrm{N}$ ratio of microbial biomass/total $\mathrm{N}$ (MBN:N), C ratio of microbial biomass $/ \mathrm{N}$ of microbial biomass ( $\mathrm{C}: \mathrm{N}$ mic), and metabolic quotient $\left(q \mathrm{CO}_{2}\right)$ calculated by the relation between the accumulated respiration and the $\mathrm{C}$ of the microbial biomass (Anderson \& Domsch, 1993), expressed in $\mathrm{mg} \mathrm{CO}_{2} \mathrm{~g}^{-1} \mathrm{CBM}$ day $^{-1}$.

\subsection{Data analysis}

The Student's t-test at $5 \%$ of significance was used to compare the attributes and microbiological indexes of the soil between the ranges of each forest fragment, using the SAEG v.9.1 statistical program. In addition, microbiological and soil chemical data were submitted to principal component analysis (PCA), with the purpose of condensing the multidimensional variation of the data in a diagram, ordering the treatments in components according to their similarities. The Canoco ${ }^{\circledR}$ v.5.0 program was used in the PCA.

In addition, Pearson correlations were established at a 5\% significance level between chemical and microbiological soil attributes, also using $\mathrm{SAEG}^{\circledast}$ v.9.1.

Table 2. Chemical characterization and soil granulometric composition in three Semi-deciduous Seasonal Forest fragments in the Southwest region of Bahia state, Brazil.

\begin{tabular}{|c|c|c|c|c|c|c|c|c|c|c|c|}
\hline Strip & pH & $\mathbf{P}$ & Al & $\mathbf{K}$ & $\mathrm{Na}$ & $\mathrm{Ca}$ & $\mathbf{M g}$ & $\mathbf{H}+\mathbf{A l}$ & Clay & Sand & Silt \\
\hline & & $\mathrm{mg} \mathrm{dm}^{-3}$ & \multicolumn{6}{|c|}{$\mathrm{cmolcdm}^{3}$} & \multicolumn{3}{|c|}{$\mathbf{g K g}^{-1}$} \\
\hline & \multicolumn{11}{|c|}{ Fragment $1^{(2)}$} \\
\hline Edge & 4.6 & 3.0 & 1.2 & 0.12 & 0.02 & 1.1 & 0.41 & 11.6 & 454.8 & 518.0 & 27.2 \\
\hline Transition & 4.4 & 3.2 & 1.5 & 0.11 & 0.03 & 0.7 & 0.26 & 11.2 & 450.0 & 516.4 & 33.6 \\
\hline Interior & 4.6 & 3.4 & 1.2 & 0.10 & 0.02 & 0.8 & 0.39 & 8.9 & 451.1 & 273.0 & 275 \\
\hline \multicolumn{12}{|c|}{ Fragment 2} \\
\hline Edge & 5.2 & 3.6 & 0.3 & 0.16 & 0.02 & 2.1 & 0.63 & 6.9 & 229.9 & 740.9 & 29.2 \\
\hline Transition & 5.0 & 4.2 & 0.5 & 0.11 & 0.01 & 1.9 & 0.51 & 6.8 & 211.8 & 762.4 & 25.9 \\
\hline Interior & 5.0 & 5.8 & 0.3 & 0.17 & 0.02 & 2.2 & 0.62 & 7.9 & 155.4 & 833.0 & 11.7 \\
\hline & \multicolumn{11}{|c|}{ Fragment 3} \\
\hline Edge & 4.8 & 3.4 & 0.9 & 0.13 & 0.02 & 1.2 & 0.51 & 9.1 & 361.6 & 610.6 & 27.8 \\
\hline Transition & 4.6 & 2.8 & 1.4 & 0.10 & 0.02 & 0.7 & 0.28 & 11.7 & 385.7 & 586.9 & 27.4 \\
\hline Interior & 4.7 & 3.2 & 1.2 & 0.11 & 0.01 & 0.7 & 0.38 & 9.4 & 308.8 & 671.7 & 19.5 \\
\hline
\end{tabular}

In which: Fragment 1: small fragment (7.3 ha); Fragment 2: medium fragment (45 ha); Fragment 3: large fragment (142 ha). 


\section{RESULTS AND DISCUSSION}

The studied soils are of high acidity and low to medium fertility. They presented clay contents varying between $199 \mathrm{~g} \mathrm{~kg}^{-1}$ (fragment 2) and $452 \mathrm{~g} \mathrm{~kg}^{-1}$ (fragment 1), with intermediate values in fragment 3 (mean of $352 \mathrm{~g} \mathrm{~kg}^{-1}$ ) (Table 2). The total $\mathrm{N}$ contents were quite close between the fragments (mean of $1.6 \mathrm{~g} \mathrm{~kg}^{-1}$ ), while the mean organic $\mathrm{C}$ contents ranged from $21.2 \mathrm{~g} \mathrm{~kg}^{-1}$ in fragment 2, to $47.3 \mathrm{~g} \mathrm{~kg}^{-1}$ in fragment 3 (Table 3). Rangel and Silva (2007) studied a Red Latosol with clayey texture (layer $0-10 \mathrm{~cm}$ ) in the Semi-deciduous Seasonal Forest in the state of Minas Gerais, observing organic $\mathrm{C}$ and total $\mathrm{N}$ levels close to those found in this work (38.9 and $1.4 \mathrm{~g} \mathrm{~kg}^{-1}$, respectively).

No significant variations were observed between fragments regarding $\mathrm{MBC}$ contents. When analyzing each of the studied areas, a variation between the strips was only observed in fragment 3 , with a higher edge value $\left(331.9 \mu \mathrm{g} \mathrm{g}^{-1}\right)$ in relation to the interior $\left(115.7 \mu \mathrm{g} \mathrm{g}^{-1}\right)$.
A similar trend was found by Freitas et al. (2008) in an Atlantic Forest remnant (Dense Ombrophilous Forest) in the state of Pernambuco, in which they observed higher values for $\mathrm{MBC}$ at the edge $\left(662.70 \mu \mathrm{g} \mathrm{g}^{-1}\right)$ in relation to the interior of the fragment $\left(367.57 \mu \mathrm{g} \mathrm{g}^{-1}\right)$. These authors observed a relationship between MBC values and soil carbon availability, which was also higher at the edge $\left(63.49 \mathrm{~g} \mathrm{~kg}^{-1}\right)$ than the interior $\left(30.59 \mathrm{~g} \mathrm{~kg}^{-1}\right)$. However, organic $\mathrm{C}$ soil levels in the present study do not explain the variation in MBC contents, since no significant differences were observed between the strips of the evaluated fragments, suggesting that other factors would favor greater carbon immobilization by microbial biomass at the edge, such as the physicochemical composition of litter accumulated on the soil. Changes in the quantity and quality of organic residues have a direct influence on the $\mathrm{C}$ contents of the soil microbial biomass, since it conditions the $\mathrm{C}$ and $\mathrm{N}$ additions to the soil (De-Polli \& Guerra, 2008).

The results of $\mathrm{MBN}$ and accumulated respiration (AR) showed no variation between the ranges of any

Table 3. Organic carbon, total nitrogen, carbon and nitrogen from microbial biomass, accumulated respiration and soil microbiological indexes in three Semi-deciduous Seasonal Forest fragments in the Southwest region of the state of Bahia, Brazil.

\begin{tabular}{|c|c|c|c|c|c|c|c|c|c|}
\hline Strip & $\mathbf{C}^{(1)}$ & $\mathbf{N}$ & MBC & MBN & $\mathbf{A R}$ & $\mathrm{C}: \mathbf{N}_{\text {mic }}$ & MBC:C & MBN:N & $q \mathrm{CO}_{2}$ \\
\hline & \multicolumn{2}{|c|}{$\mathrm{g} \mathrm{kg}^{-1}$} & \multicolumn{3}{|c|}{$\mathbf{m g} \mathbf{g}^{-1}$} & & \multicolumn{2}{|c|}{$\%$} & $\begin{array}{l}\mathrm{mg} \mathrm{g}^{-1} \\
\text { day }^{-1}\end{array}$ \\
\hline \multicolumn{10}{|c|}{ Fragment $1^{(\mathbf{1})}$} \\
\hline Edge & $38.6 \mathrm{a}$ & $2.4 \mathrm{a}$ & $275.9 \mathrm{a}$ & $66.5 \mathrm{a}$ & $215.2 \mathrm{a}$ & $4.6 \mathrm{a}$ & $0.71 \mathrm{a}$ & $3.6 \mathrm{~b}$ & $306.2 \mathrm{a}$ \\
\hline Transition & $41.4 \mathrm{a}$ & $1.7 \mathrm{a}$ & $247.3 a$ & $86.6 \mathrm{a}$ & $101.9 \mathrm{a}$ & $5.2 \mathrm{a}$ & $0.58 \mathrm{a}$ & $3.1 \mathrm{~b}$ & $165.9 \mathrm{ab}$ \\
\hline Interior & $38.9 a$ & $1.9 \mathrm{a}$ & $174.3 \mathrm{a}$ & $57.8 \mathrm{a}$ & $85.4 \mathrm{a}$ & $2.4 \mathrm{a}$ & $0.45 \mathrm{a}$ & $6.1 \mathrm{a}$ & $67.6 \mathrm{~b}$ \\
\hline Mean & $39.6 \mathrm{~B}$ & $2.02 \mathrm{~A}$ & $232.5 \mathrm{~A}$ & $70.3 \mathrm{~A}$ & $134.2 \mathrm{AB}$ & $4.0 \mathrm{~A}$ & $0.58 \mathrm{AB}$ & $4.29 \mathrm{~A}$ & $179.89 \mathrm{~A}$ \\
\hline & \multicolumn{9}{|c|}{ Fragment 2} \\
\hline Edge & $21.3 \mathrm{a}$ & $1.1 \mathrm{a}$ & $163.7 \mathrm{a}$ & $47.5 \mathrm{a}$ & $120.3 \mathrm{a}$ & $2.8 \mathrm{a}$ & $0.76 a$ & $4.5 \mathrm{a}$ & $129.5 \mathrm{ab}$ \\
\hline Transition & $31.6 \mathrm{a}$ & $1.1 \mathrm{a}$ & $137.8 \mathrm{a}$ & $40.9 a$ & $160.9 a$ & $3.3 \mathrm{a}$ & $0.43 a$ & $3.7 \mathrm{a}$ & $207.1 \mathrm{a}$ \\
\hline Interior & $31.8 \mathrm{a}$ & $1.6 \mathrm{a}$ & $176.6 \mathrm{a}$ & $69.6 \mathrm{a}$ & $137.6 \mathrm{a}$ & $2.6 \mathrm{a}$ & $0.56 \mathrm{a}$ & $5.0 \mathrm{a}$ & $103.9 b$ \\
\hline \multirow[t]{2}{*}{ Mean } & $61.7 \mathrm{~A}$ & $1.29 \mathrm{~A}$ & $159.4 \mathrm{~A}$ & $52.7 \mathrm{~A}$ & $139.6 \mathrm{~A}$ & $2.9 \mathrm{~A}$ & $0.84 \mathrm{~A}$ & $4.40 \mathrm{~A}$ & $146.83 \mathrm{~B}$ \\
\hline & \multicolumn{9}{|c|}{ Fragment 3} \\
\hline Edge & $42.9 \mathrm{a}$ & $1.4 \mathrm{a}$ & $331.9 \mathrm{a}$ & $56.9 \mathrm{a}$ & $110.4 \mathrm{a}$ & $5.5 \mathrm{a}$ & $0.78 \mathrm{a}$ & $4.8 \mathrm{a}$ & $84.6 \mathrm{~b}$ \\
\hline Transition & $47.2 \mathrm{a}$ & $1.6 \mathrm{a}$ & $166.1 \mathrm{ab}$ & $48.7 \mathrm{a}$ & $94.9 \mathrm{a}$ & $3.9 \mathrm{ab}$ & $0.35 b$ & $3.7 \mathrm{a}$ & $149.7 b$ \\
\hline Interior & $51.8 \mathrm{a}$ & $1.5 \mathrm{a}$ & $115.7 \mathrm{~b}$ & $65.4 \mathrm{a}$ & $141.7 \mathrm{a}$ & $1.71 \mathrm{~b}$ & $0.23 \mathrm{~b}$ & $4.8 \mathrm{a}$ & $257.4 \mathrm{a}$ \\
\hline Mean & $47.3 \mathrm{AB}$ & $1.53 \mathrm{~A}$ & 204.6 A & $57.0 \mathrm{~A}$ & $115.7 \mathrm{~B}$ & $3.7 \mathrm{~A}$ & $0.45 \mathrm{~B}$ & $4.44 \mathrm{~A}$ & $163.91 \mathrm{AB}$ \\
\hline
\end{tabular}

In which: Fragment 1: small fragment (7.3 ha); Fragment 2: medium fragment (45 ha); Fragment 3: large fragment (142 ha); C: Organic carbon; N: Total Nitrogen; MBC: Microbial biomass C; MBN: Microbial biomass N; AR: Accumulated respiration; C: $\mathrm{N}_{\text {mic }}$ : C ratio of microbial biomass:microbial biomass N; MBC:C: C ratio of microbial biomass: organic C; $\mathrm{MBN}: \mathrm{N}: \mathrm{N}$ ratio of microbial biomass: total N; $q \mathrm{CO}_{2}: \mathrm{Metabolic}$ quotient. Means followed by the same lower case or upper case letter in the column do not differ from one another by the $\mathrm{t}$-test at $5 \%$. 
of the three studied fragments (Table 3). Similar results were reported by Silva et al. (2012), who also did not observe significant differences in MBN between secondary forests in different successional stages: initial $\left(37 \mathrm{mg} \mathrm{kg}^{-1}\right)$, intermediate $\left(48 \mathrm{mg} \mathrm{kg}^{-1}\right)$, and advanced $\left(35 \mathrm{mg} \mathrm{kg}^{-1}\right)$.

The MBN:N ratio only showed a distinction between strips in the smallest fragment, ranging from 3.1 to $6.1 \%$, with higher value in the interior and lower in the edge and transition strip (Table 3), which suggests that the biomass in the conditions of the interior yields greater efficiency in the conversion of soil nitrogen to microbial $\mathrm{N}$.

On the other hand, the MBC:C ratio only varied significantly in the larger fragment, with lower value in the interior and transition $(0.23 \%)$ in relation to the edge $(0.78 \%)$. This is an indication that, under edge conditions, microbial biomass would be acting on better quality organic matter, since higher values of this ratio indicate greater efficiency in the conversion of soil carbon into microbial C (Wardle, 1992). These results corroborate previously discussed results and may be related to the occurrence of a higher proportion of pioneer leguminous species at the edge, which would be contributing to depositing plant residues with higher nutritional quality with high levels of $\mathrm{N}$. In this sense, Malmivaara-Lämsä et al. (2008) evaluated urban forest fragments of boreal vegetation in Finland and observed that the C:N ratio of the soil increased in the edge-interior direction of the fragments. However, in this study, the C:N ratio of the soil varied little within the fragments.

The C: $\mathrm{N}_{\text {mic }}$ ratio also only showed significant differences between strips in fragment 3 , being smaller in the interior (1.7) in relation to the edge (5.5) (Table 3). Lower values of this ratio demonstrate greater efficiency of microbial biomass in immobilizing soil carbon and nitrogen (Wardle, 1992). Therefore, the observed results indicate that the performance of the edaphic microbiota on the border, when compared to the interior, would be hindered, possibly due to another stress condition or higher recalcitrance of the organic matter.

The absence of variation of MBC, $\mathrm{C}: \mathrm{N}_{\text {mic }}$ and MBC:C indices between the strips of fragments 1 and 2 may be related to the influence of size and isolation of the fragments (Table 1), which made the transition strip and interior of these fragments more susceptible to the changes caused by the edge effect. In other words, this would be providing a more vulnerable state of conservation throughout fragments 1 and 2, while because fragment 3 has a larger area and proximity index (Table 1), this would allow greater preservation of the characteristics of its interior, thus differing from the edge. Oliveira \& Mattos (2014) point out that smaller fragments tend to suffer greater interferences from external factors, and therefore the internal dynamics end up losing strength from the influence that the surroundings of the fragment exerts.

The $q \mathrm{CO}_{2}$ was the index that was more responsive to the environment variations, since it presented differentiation between the strips of the three studied fragments. The lowest values in fragments 1 and 2 were observed in the interior in relation to the edge and transition (Table 3). This result suggests that in the strips near the edge, the soil microbial population is in a more stressful condition, probably due to the greater influence of the external environment.

Freitas et al. (2008) observed greater microbial activity at the edge when compared to the interior of an Atlantic Forest fragment, attributing the result to the effect of stress on soil microorganisms, which would result in high nutrients cycling. In evaluating the quality of soils under different vegetation cover, Jakelaitis et al. (2008) verified lower $q \mathrm{CO}_{2}$ values in native vegetation $\left(0.05 \mu \mathrm{g}\right.$ of $\mathrm{CO}_{2} \mu \mathrm{g}$ biomass ${ }^{-1}$ day $\left.^{-1}\right)$ compared to pasture areas $\left(0.17 \mu \mathrm{g}\right.$ of $\mathrm{CO}_{2} \mu \mathrm{g}$ biomass ${ }^{-1}$ day $\left.^{-1}\right)$ and corn cultivation $\left(0.18 \mu \mathrm{g}^{-1}\right.$ day $\left.^{-1}\right)$, noting the efficiency of using $q \mathrm{CO}_{2}$ as an indicator of stress or functional imbalances in the environment.

However, a contrasting trend was observed in fragment 3 , with higher $q \mathrm{CO}_{2}$ values in the interior and lower in the edge and transition (Table 3 ). This result may be related to differences in the $\mathrm{C}: \mathrm{N}$ ratio of the soil between the sampling ranges, since a significant positive correlation was verified between the $q \mathrm{CO}_{2}$ and the C:N ratio of the soil under this fragment $(\mathrm{p}<0.05$, $r=0.73$ ). According to Paul (2016), soil respiration (and as a consequence the metabolic quotient) are influenced by several factors such as humidity, temperature, nutrient availability and soil C:N ratio.

For the smaller fragment, the PCA presented eigenvalues of $64.4 \%$ for the first axis (horizontal, PC1) and $35.6 \%$ for the second axis (vertical, PC2). The graphical dispersion (Figure 1A) shows that there was dissimilarity between edge, transition and interior of 
the fragment. The location of the interior to the right of the diagram, near PC1, is due to the MBC, AR and $\mathrm{N}$ values verified in this range, considering that these variables were the most important for explaining the variance of the first axis. These same variables also explain the positioning of the edge to the left of the graph, between PC1 and PC2. On the other hand, the location of the transition to the left, very close to PC2, shows that organic $\mathrm{C}$, an attribute most correlated with the second axis, was the most influential characteristic for differentiation of this range.

The eigenvalues found in the PCA of the middle fragment (Figure 1B) were 55.6\% (PC1) and 44.4\% (PC2). The positioning of the transition to the right of the ordering diagram, next to $\mathrm{PC} 1$, shows that $\mathrm{MBC}, \mathrm{AR}$ and MBN attributes are more correlated with the first axis, and were the characteristics of greater influence for differentiation of this range. The location to the left of the edge (upper quadrant) and inner (lower quadrant) charts, close to PC2, was determined by the variables total $\mathrm{N}$ and organic $\mathrm{C}$.

In relation to the large fragment, eigenvalues in PCA were obtained from $54.3 \%$ for PC1 and $45.7 \%$ for PC2 (Figure 1-C). For the first axis, the most discriminant variables in evaluating the variation between the strips were organic $\mathrm{C}$ and $\mathrm{AR}$, while for PC2 the most important variables were total $\mathrm{N}$ and MBN. The location of the edge to the left of the graph, close to $\mathrm{PC} 1$, shows that $\mathrm{MBC}$ was the most influential characteristic for differentiation of this range.

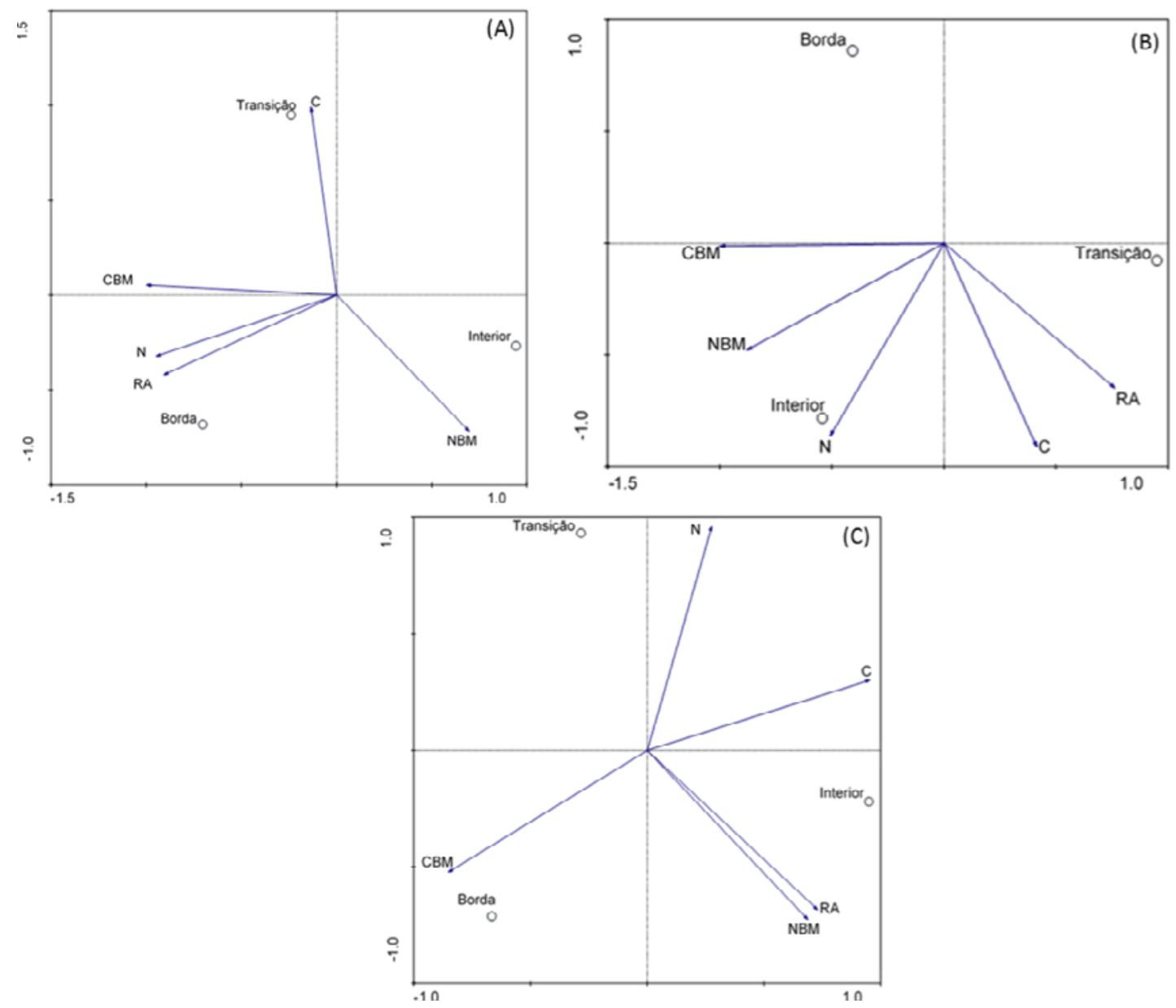

Figure 1. Ordering diagram produced by the analysis of main components of the soil attributes in the sample ranges of the fragments: small (A), medium (B) and large (C). C: organic carbon; N: total nitrogen; MBC: microbial biomass C; MBN: microbial biomass N; AR: accumulated respiration in relation to the border, transition and interior of the fragments. 
The PCA in the three forest fragments showed low grouping of the strips, which were distributed in different quadrants, although with a slight approximation of the characteristics of the edge in relation to the transition, indicating a dissimilarity between the strips with respect to the evaluated attributes. This result suggests differentiation of the soil microbial biomass efficiency in immobilizing $\mathrm{C}$ and $\mathrm{N}$ in the three considered conditions. In working with native forest soils and agricultural and pasture areas, Silva et al. (2012) verified that the $\mathrm{MBC}, \mathrm{MBN}$ and arylsulfatase enzyme contents were the higher correlated attributes with the first ordering axis, enabling differentiation of two groups; one formed by agricultural areas and another by native forest and pasture. Also using principal component analysis to interpret the relationship of chemical and microbial attributes in soils under different eucalyptus plantations, Barreto et al. (2008) observed that the organic $\mathrm{C}$ and total $\mathrm{N}$ contents were the attributes of greater correlation with the first axis, concluding that these were more discriminating indicators than microbial biomass to measure variations between plantations.

The results obtained in this study reveal that the fragment size conditions the degree of influence of the external environment, taking smaller fragments to a status of similar edge effect throughout its extension and consequently a worse state of conservation. Thus, the greater edge-interior distance in large fragments would favor maintaining the natural characteristics of the microbial biomass of the soil inside due to the lower effect of the external environment.

\section{CONCLUSIONS}

The $\mathrm{MBC}, q \mathrm{CO}_{2}$, and the $\mathrm{C}: \mathrm{N}_{\text {mic }}, \mathrm{MBC}: \mathrm{C}$ ratios are discriminating indicators of the edge effect on the biological quality of the soil of the studied forest fragments. The integrated analysis of different soil microbiological attributes is adequate to evaluate the edge effect in forest fragments.

The fragment size and their isolation condition the influence level of the edge effect on the biomass and microbial activity of the soil. Smaller-sized fragments are more vulnerable to the actions of the external environment in all their extension, while larger fragments present greater capacity to preserve the characteristics of their interior.

\section{SUBMISSION STATUS}

Received: 11 Oct., 2017

Accepted: 24 Nov., 2018

\section{CORRESPONDENCE TO}

\section{Patrícia Barreto-Garcia}

Universidade Estadual do Sudoeste da Bahia, Estrada do Bem Querer, km 4, CEP 45031-300, Vitória da Conquista, BA, Brasil e-mail: patriciabarreto@uesb.edu.br

\section{FINANCIAL SUPPORT}

Fundação de Amparo à Pesquisa do Estado da Bahia.

\section{REFERENCES}

Anderson TH, Domsch KH. The metabolic quotient from $\mathrm{CO}_{2}\left(q \mathrm{CO}_{2}\right)$ as a specific activity parameter to assess the effects of environmental conditions, such as $\mathrm{pH}$, on the microbial biomass of forest soils. Soil Biology and Biochemistry 1993; 25(3): 393-395. 10.1016/00380717(93)90140-7

Araújo ASF, Monteiro RTR. Indicadores biológicos de qualidade do solo. Bioscience Journal 2007; 23(3): 66-75. 10.1590/S1413-70542009000400010

De-Polli H, Guerra JGM. Carbono, nitrogênio e fósforo na biomassa microbiana do solo. In: Santos GA, Silva LS, Canellas LP, Camargo FAO, editores. Fundamentos da matéria orgânica do solo: ecossistemas tropicais \& subtropicais. 2nd ed. Porto Alegre: Metrópole; 2008. p. 263-276.

Empresa Brasileira de Pesquisa Agropecuária - Embrapa. Manual de métodos de análise de solo. 2nd ed. Rio de Janeiro: Embrapa; 1997.

Freitas NO, Silva FSB, Maia LC. Edge effect on soil biochemical and microbiological activities in an Atlantic Forest fragment in the state of Pernambuco, Brazil. Bioremediation, Biodiversity and Bioavailability 2008; 2: 62-67.

Gama-Rodrigues EF, Gama-Rodrigues AC. Biomassa microbiana e ciclagem de nutrientes. In: Santos AS, Silva SS, Canellas LP, Camargo FDE, editores. Fundamentos da matéria orgânica do solo: ecossistemas tropicais \& subtropicais. Porto Alegre: Metrópole; 2008. p. 159-168.

Holanda AC, Feliciano ALP, Marangon LC, Santos MS, Melo CLSMS, Pessoa MML. Estruturas de espécies arbóreas sob efeito de borda em um fragmento de Floresta Estacional Semidecidual em Pernambuco. Revista Árvore 2010;34(1): 103-114. 10.1590/S0100-67622010000100012 
Instituto Brasileiro de Geografia e Estatística - IBGE. Manual técnico da vegetação brasileira. 2nd ed. Brasília, DF: IBGE; 2012.

Instituto de Estudos Socioambientais do Sul da Bahia Iesb. Levantamento da cobertura vegetal nativa do bioma Mata Atlântica. Rio de Janeiro: Iesb; 2007.

Jakelaitis A, Silva AA, Santos JB, Vivian R. Qualidade da camada superficial de solo sob mata, pastagens e em áreas cultivadas. Pesquisa Agropecuária Tropical 2008; 38: 118-127. 10.5216/pat.v38i2.4171

Laurance WF, Merona JMR, Andrade A, Laurance SG, D'Angelo S, Lovejoy TE et al. Rain-forest fragmentation and the phenology of Amazonian tree communities. Journal of Tropical Ecology 2003; 19(3): 343-347. 10.1017/ S0266467403003389

Laurance WF, Camargo JLC, Luizão RCC, Laurance SG, Pimm SL, Bruna EM et al. The fate of Amazonian forest fragments: a 32-year investigation. Biological Conservation 2011; 144(1): 56-67. 10.1016/j.biocon.2010.09.021

Malmivaara-Lämsä M, Hamberg L, Haapamäki E, Fritze $H$. Edge effects and trampling in boreal urban forest fragments: impacts on the soil microbial community. Soil Biology and Biochemistry 2008; 40: 1612-1621. 10.1016/j. soilbio.2008.01.013

Martinkoski1 L, Vogel GF, Jadoski SO, Watzlawick LF. Qualidade física do solo sob manejo silvipastoril e floresta secundária. Floresta e Ambiente 2017; 24: e20160282. $10.1590 / 2179-8087.028216$

Murcia C. Edge effects in fragmented forests: implications for conservation. Trends in Ecology e Evolution 1995; 10: 58-62. 10.1016/S0169-5347(00)88977-6

Oliveira FFG, Mattos JT. Análise ambiental de remanescentes do bioma Mata Atlântica no litoral sul do Rio Grande do Norte - NE do Brasil. Geousp: Espaço e Tempo 2014; 18(1): 165-183. 10.11606/issn.2179-0892. geousp.2014.81095

Padilha KM, Freire MBGS, Duda GP, Santos UJ, Silva $\mathrm{AO}$, Souza ER. Indicadores biológicos de dois solos com a incorporação de subproduto da agroindústria de café. Revista Brasileira de Ciência do Solo 2014; 38: 1377-1386. 10.1590/S0100-06832014000500003

Paul EA. The nature and dynamics of soil organic matter: plant inputs, microbial transformations, and organic matter stabilization. Soil Biology and Biochemistry 2016; 98: 109-126. 10.1016/j.soilbio.2016.04.001
Pôrto ML, Alves JC, Diniz AA, Souza AP, Santos D. Indicadores biológicos de qualidade do solo em diferentes sistemas de uso no Brejo Paraibano. Ciência e Agrotecnologia 2009; 33(4): 1011-1017. 10.1590/S141370542009000400010

Rangel OJP, Silva CA. Estoques de carbono e nitrogênio e frações orgânicas de Latossolo submetido a diferentes sistemas de uso e manejo. Revista Brasileira de Ciência do Solo 2007; 31: 1609-1623. 10.1590/S010006832007000600037

Riguete JR, Dornellas EEJ, Teixeira NB. Avaliação do efeito de borda em fragmento florestal tomando o diâmetro de árvores como indicador. Natureza Online 2013; 11(4): 193-195.

Santos BC, Rangel LA, Castro E. Estoque de matéria orgânica na superfície do solo em fragmentos florestais de Mata Atlântica na APA de Petrópolis-RJ. Floresta e Ambiente 2011; 18(3): 266-274. 10.4322/ floram.2011.047

Silva CF, Pereira MG, Miguel DL, Feitora JCF, Loss A, Menezes CEG et al. Carbono orgânico total, a biomassa microbiana e atividade enzimática do solo de áreas agrícolas, florestais e pastagem. Revista Brasileira de Ciência do Solo 2012; 6(6): 1680-1689. 10.1590/S010006832012000600002

Silva JMC, Pinto LP, Hirota M, Bedê L, Tabarelli M. Conservação da Mata Atlântica brasileira: um balanço dos últimos dez anos. In: Cabral DC, Bustamant EAG, organizadores. Metamorfoses florestais: culturas, ecologias e as transformações históricas da Mata Atlântica. Curitiba: Prismas; 2016. p. 434-460.

Tate KR, Ross DJ, Feltham CW. A direct extraction method to estimative soil microbial C: Effects of experimental variables and some different calibration procedures. Soil Biology and Biochemistry 1988; 20: 329-335. 10.1016/ 0038-0717(88)90013-2

Vidal MM, Pivello VR, Meirelles ST, Metzger JP. Produção de serapilheira em floresta Atlântica secundária numa paisagem fragmentada (Ibiúna, SP): importância da borda e tamanho dos fragmentos. Revista Brasileira de Botânica 2007; 30(3): 521-532. 10.1590/S010084042007000300016

Wardle DAA. A comparative assessment of factors which influence microbial biomass carbon and nitrogen levels in soil. Biological Reviews 1992; 67: 321-358. 10.1111/j.1469185X.1992.tb00728.x 